\title{
Pastors or Lawyers? The Role of Religion in the South African Truth and Reconciliation Commission Process ${ }^{1}$
}

\author{
P G J Meiring \\ Department of Science of Religion and Missiology \\ University of Pretoria
}

\begin{abstract}
In this article, Piet Meiring who served as Committee Member on the TRC discusses the often disputed religious character of the Commission. Quoting examples from the TRC process he describes the debate that developed - on Archbishop Tutu's religious way of handling the affairs of the Commission. Meiring discusses the TRC liturgy that was developed during the course of the process, as well as how important the role of religion proved to be in terms of three crucial issues: the process of remembering, the quest for truth, and the costliness of reconciliation.
\end{abstract}

\section{INTRODUCTION}

The work of the South African Truth and Reconciliation Commission (TRC) has captured the imagination of many, locally as well as abroad. The process of the commission instituted to promote national unity and reconciliation by establishing as complete a picture as possible of the suffering of the many victims of apartheid, by facilitating amnesty to perpetrators of apartheid who make full disclosure of all the relevant facts relating to their acts, and to make recommendations to the President of South Africa with regard to the granting of reparation to the victims and their families, as well as re-

\footnotetext{
1 This article is based on a chapter written by the author in Looking back: reaching forward, 123-131, (editors C VillaVicensio \& W Verwoerd), Cape Town: UCT Press, 2000.
} 
commendations on measures to prevent future violations of human rights (TRC Report, Vol 1:55-57) - has been subjected to thorough investigation and analysis.

One aspect that never ceases to catch the attention of commentators and researches alike is the religious character of the TRC. According to Alex Boraine who served as vice chairperson of the Commission, it was evident from the very beginning that there would be both praise and critisism for the way in which Archbishop Desmond Tutu - openly wearing his ecclesiastical dress, offering prayers and often using Christian metaphor - handled the affairs of the TRC (Boraine 2000:266).

At the TRC's very first public hearing at East London (April 1994) Boraine voiced his concern about the fact that some in the audience may object to the archbishop wearing his purple clercical robes. Tutu replied: "The president knew that I was an Archbishop when he appointed me!" - and continued to announce a hymn and to open the proceedings with a prayer (Boraine 2000:101).

The concern and the question, however, continued to surface. At the first hearing in Johannesburg, a few days later Fazel Randera, chief of the Johannesburg office, again spoke to Tutu about the issue. Allow me to quote from my diary (Meiring 1998:29).

"No! This is not the way to do it." Archbishop Desmond Tutu, who was to chair the first Johannesburg hearing of the Truth and Reconciliation Commission, looked his audience straight in the eye. Earlier in the morning, in the vestry of the Central Methodist Church where the hearing was scheduled to take place, Dr Fazel Randera, chief of the Johannesburg office of the TRC, discussed the proceedings of the coming days with the Archbishop. Nothing was left to chance. This hearing (from 29 April to 3 May 1996) would set the pattern for many to follow. The world media would be present and most of the diplomatic corps accepted invitations to attend. Politicians and senior government officials indicated that they also would attend. Former President Nelson Mandela was to make an appearance.

Fazel Randera, together with a number of colleagues, voiced their concern. The previous hearing, in East London, as well as numerous TRC ceremonies of the previous weeks, were far too "religious" for their taste. The many prayers, the hymn-singing before and during the hearings and the religious wrappings of the process were out of place. The TRC process was a 
legal process and should be conducted in a juridical style. That Desmond Tutu arrived at most hearings wearing his archbishop's vestment, complete with clerical collar and crucifix, they had to accept. But, surely, it was a juridical hearing in Johannesburg, and not a Sunday service in the St George's Cathedral in Cape Town, that was to take place today as well as in the days to follow. "Of course we need a solemn and dignified opening," Fazel explained, "but why not follow the example of Parliament these days. Let us have a moment of silence - of quiet meditation for those who felt like it - and get on with the programme."

Tutu gamely accepted Fazel's suggestion: "It is the Johannesburg office's hearing. I will do as you say.” At the stroke of $9 \mathrm{a} \mathrm{m}$, the TRC procession moved into the hall. One after the other, Tutu and his colleagues shook hands with the victims in the first three rows. He proceeded to the stage to address the audience. "We will observe half a minute's silence," he said, "before we commence with our programme." The first witness was announced and asked to take the oath. The stage was set.

But Tutu was patently uncomfortable. He was unable to start with the proceedings. He shifted the papers on the table in front of him. He cleared his throat. When he spoke to the audience, he said: "No! This is not the way to do it. We cannot start without having prayed. Close your eyes!” In his inimitable way, the Archbishop placed the hearing of the day in the Lord's hands, asking that Jesus Christ, who himself is the Truth, guide us in our quest for truth, that the Holy Spirit of God grant us the wisdom and grace we need. After a resounding "amen", he announced with a disarming smile: "So! Now we are ready to start the day’s work...” Fazel and his colleagues equally gamely accepted the Archbishop’s instinct and ruling. From that day onwards all TRC hearings were to start - and be closed - in a proper fashion.

\section{THE BARUTI VERSUS THE LAWYERS}

This does not mean that the debate on the role that religion had to play during the process, on the religious trappings of the TRC, had been resolved. Right to the end of the life of the TRC, voices within and without the TRC made themselves heard on the subject. The four baruti (the pastors) among the TRC commissioners and committee members, together with a number of colleagues, most of them staunch churchgoers, 
strongly identified with the Archbishop's sentiments in this regard. Others - the lawyers, the politicians and some of the academics serving on the TRC - sympathized with Fazel Randera. It was a friendly debate, each allowing the other their views on the matter, but it did raise a number of issues that were difficult to answer. Right at the end of the life of the TRC when the Final Report was tabled, Commissioner Wynand Malan, lawyer by training and senior politician, submitted a Minority Report in which he again voiced his concern about the role of religion in the process (TRC Report, Vol 5:439-441).

From outside the ranks of the TRC the debate carried on, with equal verve. Heated arguments were presented by a number of NGO's, by political groupings and by the public at large. One of the sharpest comments was from Cosmas Desmond, a former Catholic priest, who campaigned during the last election as a member of the Pan Africanist Congress (PAC). He was concerned about the fact that besides Desmond Tutu (obviously appointed to the TRC “to be John the Baptist to Mandela’s messiah”), four other churchmen - together with activists, who in the past had close connections with ecumenical bodies - were appointed to the TRC. The churches were over-represented on the Commission, Cosmas Desmond retorted, and this did not bode well for the work of the TRC (The Star, 29 February 1996).

Such is that over-representation that the question arises as to whether the TRC is an arm of the state or the church. Most church leaders, including Archbishop Tutu, agreed that the new South Africa would be a secular state. Yet the first meeting of the Commission's Reparations Committee was opened not only with prayer but with an exclusive Christian one. And it appears to be assumed that all decisions of the Commission will be informed by Christian values. This would not be bad - though it would still be unacceptable to some - if the norms or values were indeed Christian. But the word "Christian" is all too often simply a synonym for "Western." This is clearly illustrated in the Commission's individualistic understanding of human rights and their violation, rather than a more African (and, I would contend, more Christian) approach.

From the other extreme of the political spectrum Dan Roodt, outspoken Afrikaner intellectual, equally vehemently attacked the TRC, inter alia for the religious trappings of 
the Commission's process. To his way of thinking, the TRC was nothing less than old fashioned nineteen century colonialism brought to life again, a brand of colonialism of which the English churches - with their traditional contempt for both the Afrikaner and indigenous Black culture - were especially guilty (Roodt 2000:120f).

\section{TRC “LITURGY"}

Looking at the situation from the outside, the strong emphasis on the religious aspects of the TRC process should have been expected. The South African community is by and large a religious community. The vast majority of South Africans belong to one of the Christian denominations or to the Muslim, Hindu, Buddhist, Bahai, Jewish or African traditionalist communities. Although many serious questions may be raised about the commitment of many of the adherents - the percentage of purely nominal membership is steadily climbing - the influence of the churches and other faith communities is still a force to be reckoned with. From the onset, the faith communities were involved in discussing the possibility of a truth commission and eventually in the drafting of the TRC Act. Workshops and conferences to further the aims of the TRC and to identify the churches' and other communities' role in the process were the order of the day. And when the TRC hearings started, the local churches were the staunch co-workers of the Commission, helping to disseminate news, to encourage victims and perpetrators to approach the TRC and to act as facilitators and spiritual guides throughout the life of the Commission.

Early in the life of the TRC, a TRC "liturgy" spontaneously developed, which very soon set the pattern for most of the Truth Commission hearings throughout the country. At the Service of Dedication and Blessing of Commissioners of the Truth and Reconciliation Commission in St George's Cathedral in Cape Town (13 February 1996), a dignified "order of worship" was introduced: the singing of hymns, prayers (interdenominational and inter-faith), readings in many languages, the lighting of candles and the presenting of olive branches. These elements were repeated at most hearings in many parts of the country. Archbishop Tutu, with his sense of occasion as well as his intuitive understanding of the spiritual needs of the victims and the audience, made ample use of 
the hymns and prayers not only to open and close the meetings but to guide the process through difficult, sometimes traumatic, moments.

At the TRCs first victims' hearing (East London, 19 April 1996), Mrs Nomonde Calata, widow of Fort Calata (one of the "Cradock Four"), was momentarily overcome with grief, while relating the story of her husband's abduction and murder. Her anguished wails filled the hall. The audience and the Commissioners at the table were shocked into silence. When Tutu, after allowing a few minutes for Mrs Calata to compose herself, needed to start the session again, he intoned in his own voice the Xhosa hymn Senzeni na (“What have we done?") Everyone, even the journalists and security personnel, joined in the singing. Tears flowed. But the atmosphere was set for the rest of the day. The lesson was properly learnt and at many future meetings, in a particularly difficult situation, the singing of a hymn or a prayer saved the day (Meiring 1998:24, cf Krog 1998:42f).

\section{SPIRITUAL WELLS}

The role played by the faith communities went far beyond mere reflection on the TRC process and the provision of local infrastructures and services, even of providing a "liturgy" for the hearings. In the quest for truth and reconciliation - for the eventual healing of the nation - the spiritual contributions of the different faith communities were of extreme importance. "Religion is central to this process of healing" wrote Tutu six months into the life of the TRC. "We need to reach deep into the spiritual wells of our different religious traditions practiced in this country in order to draw strength and grace with which to address the challenges of healing and of nation building” (Bothman 2000:8). He added - providing an answer for Cosmas Desmond's objections - "Those of us who stand within the Christian tradition have, perhaps, a special responsibility in this regard, because this nation has through the years employed Christian theological resources to promote apartheid - a system that is today accepted by people throughout the world as a crime against humanity" (Bothman 2000:8) At the Faith Communities' hearing in East London (17-19 November 1997), representatives of the "other" communities - the Jewish, Muslim, Hindu and African traditionalist - were able to table a number 
of religious and ethical principles that could be of extreme value to the process of truth and reconciliation in the country.

\section{THREE CRUCIAL ISSUES}

I would like to touch on three issues in this regard: the process of remembering, the quest for truth and the costliness of reconciliation.

\subsection{Remembering}

After 1994, it is often said, South Africans leap-frogged from a time of pain and struggle right across to a time of jubilation and celebration - forgetting that in-between the two poles we owe ourselves a time of remembrance, a time of mourning. To neglect this "middle time”, the season of remembering and mourning, means not only to impoverish our national life, but to miss opportunity to deal with the ghosts of the past, ghosts which surely will return to haunt us for decades to come. "Of course we need to close the books (on the past)" the Chairperson of the TRC often told audiences, "But the books must first be opened ...” (Meiring 1998:11). Bettelheim has commented: "What cannot be talked about, cannot be put to rest, and if it is not, the wounds will continue to fester from generation to generation” (quoted from a Reparation and Rehabilitation Discussion Paper).

The religious beliefs and experiences of many South Africans facilitated this process. Father Michael Lapsley, himself a victim of the struggle, who was severely and permanently injured by a letter bomb and who was instrumental in conducting a series of "healing of memories" workshops throughout the country, wrote: "For Christians, we need to remind ourselves that we belong to a remembering religion. "Remember when you were slaves in Egypt” is a constant refrain of the Old Testament... The words of Jesus - "Do this in memory of me” - are said at every Eucharist” (Bothman 2000:22f).

Christians should be willing to remember, and eventually to forgive, Lapsley contended. We should not allow our memories to destroy us. Forgiveness is always the Christian calling, "but no one should suggest that forgiveness is glib, cheap or easy. What does it mean to forgive those who have not confessed, those who have not changed their lives, those who have no interest in making it up to the relatives of victims and the 
survivors of their crimes? If you forgive a murderer, does that mean that there should be no justice?”

Remembering means that victims should be provided the opportunity to tell their stories and that others - perpetrators, bystanders, the general public and the nation as a whole - are willing to sit down and listen. We need one another's stories. Stories become the glasses through which we look at one another's lives, the heartthrob by which we experience each other's anguish and pain, as well as our triumphs and our peace. Not to listen is the final insult. Eli Wiesel, who spent his life documenting Nazi atrocities, once remarked (quoted by Villa-Vicensio, in The Sunday Independent, 7 June 1998):

At the risk of offending, it must be emphasized that the victim suffered more profoundly from the indifference of the onlookers than from the brutality of the executioner. The cruelty of the enemy would have been incapable of breaking the prisoner; it was the silence of those he believed to be this friends - cruelty more cowardly, more subtle - which broke his heart.

During the TRC hearings, the Commissioners presiding at the table often called upon the victims and their relatives to allow their deep-seated religious beliefs, as well as the support they were receiving from their faith communities, to sustain them through this process of mourning and remembering. According to the testimony of many, it often happened that a painful, traumatic appearance before the TRC was transformed into a cathartic experience. The tears, regularly seen on television newscasts at night, were mostly tears of healing. On the other hand, the many instances when believers especially from the white community - failed to be present at the hearings, when they chose to ignore the stories, failed to "sit where they sit" (Ezekiel 3:15), indicate a missed opportunity but also serve as an accusation with which they will have to live for decades to come.

\subsection{Truth}

Central to the mandate of the TRC was to try and establish the truth about the past - in the words of the then Minister of Justice Dullah Omar, when he introduced the TRC legislation to Parliament, to join in the search for truth without which there can be no 
genuine reconciliation (Meiring 1998:12-14). I still remember the long discussions we had in the TRC office in Johannesburg. How does one establish the truth? Modesty, it seemed, becomes everyone in their search for truth. We took some courage from the often quoted words of Michael Ignatief that although we will never be able to present a perfect picture, to establish the final truth, what the TRC indeed should be able to do was "to curtail the number of lies that up to now had free reign in society" (Meiring 1998:357). Not everyone was convinced about the Truth Commission's success in this regard, among them Anthea Jeffery who raised a number of serious critisisms against, inter alia, the TRC's handling of the "truth" (Jeffery 1999:13).

The quest for truth, also had a deeper side to it. Searching for the truth, in the tradition of all religions, is a spiritual exercise. Finding the truth goes well beyond establishing historical and legal facts. It has to do with understanding, accepting accountability, justice, restoring and maintaining the fragile relationships between human beings, as well as with the quest to find the Ultimate Truth, God Himself. Leading the nation on this road indeed posed a huge challenge to the faith communities in the country. The search for truth needed to be handled with the greatest sensitivity. Would that not be the case, the nation could bleed to death. But if we succeeded, it would lead to a national catharsis, peace and reconciliation, to the point where the truth in all reality sets one free.

I have seen this happen. When a perpetrator, after much anguish and embarrassment, eventually unburdened himself to the Amnesty Committee, when he made submission of all the relevant facts, after the questioning and cross-examination had come to an end, it was as if a cloud was lifted. On the last day of his appearance before the TRC, when he had to testify to his role in the Khotso House bombing, ex-Minister of Police Adrian Vlok told me: "When the final question was asked and when the legal team of the South African Council of Churches indicated it's satisfaction - that the team was willing not to oppose my amnesty application - my heart sang. I got a lump in my throat and I thanked God for his grace and mercy to me” (Meiring 1998:357).

Victims experienced the same. The truth did indeed set them free. After a particularly difficult testimony at an East London hearing, when an aged Xhosa woman described the terrible tortures inflicted on her 14-year-old son, a story that had most of the audience struggling with their emotions, the women remarked on the blessing of 
being given the opportunity to place the truth - her truth - on the table. "Oh yes, Sir, it was worth the trouble (to testify). I think that I will immediately fall asleep tonight, for the first time in sixteen years, and will not have nightmares (again)” (Meiring 1998:371).

\subsection{Reconciliation}

More difficult even that the quest for truth is the quest for reconciliation. The rather naive expectation - at the onset of the TRC's work - that once we have welcomed truth in at the front door of our house, reconciliation would slip in by the back door, proved to be wrong. There were instances of reconciliation among perpetrators and victims. Desmond Tutu remarked: "Sometimes the Lord knocked your feet out from underneath you when things happened at the most unexpected times and places ... (when we experienced) the mercy and generosity and forgiveness he planted in people's hearts. Our God is truly a God of surprises!” (Meiring 1998:376f, cf Tutu 1999:127, 218ff).

One of the major difficulties we had to face was that of definition. What does reconciliation really mean? What does it entail? Lengthy discussions were held at TRC meetings. On the one hand, there were lawyers, jurists and politicians who, with feet planted firmly on the ground, warned that we should not be too starry-eyed when we speak about reconciliation. When the dust settles in the streets, when the shooting stops, when people let go of one another's throats, we needed to be grateful. That is enough! That is, in our context, as far as reconciliation goes. Archbishop Tutu and the baruti, on the other hand, favoured a far more lofty definition. When they spoke about reconciliation they clothed it in religious terminology. Referring to Paul's Second Letter to the Corinthians, it was often said that only because God had reconciled us to Him by sacrificing his Son Jesus Christ on the cross, true and lasting reconciliation between humans became possible (2 Cor 5:17-12). Trying to define reconciliation, references were often made to the shalom, the peace that God alone could provide. Psalm 85:10-14 was often quoted. In similar fashion, spokespersons for the other faith communities used deeply religious terminology, referring to the deepest sources of their beliefs, when they joined in the debate. 
On one issue there was total agreement. Reconciliation was a costly and very fragile exercise. Also that it would be impossible to refer to reconciliation without also taking into account the issues of justice, accountability and restitution. And to help this process to succeed, each of the faith communities carried an inescapable responsibility.

\section{FAITH COMMUNITIES’ HEARING}

How big a responsibility the churches and the other faith communities had became evident at the special hearing in East London in November 1997. Representatives of 41 denominations and religious groups were invited to comment on their most fervent beliefs on the abovementioned issues and given an account of their conduct during the apartheid years. It proved a humbling experience for all groups - not only for the Afrikaans churches that were traditionally at the side of the previous government (even to the point of providing a theological argument for apartheid) but also the churches and communities on the "other side", who traditionally opposed apartheid. Not one community remained untouched and uncontaminated by the past. There was a lot to confess to one another, and much to be forgiven (Meiring 1998:265-285).

But there were also dreams to share and commitments to make. My lasting impression of the East London hearing was that of a community of believers - Christians, Muslims, Hindus, Jews, Buddhists and African traditionalists - who took hands to move into the future together, devoted to the process of truth and reconciliation. As to affirm their resolve, a number of far-reaching proposals to the faith communities in South Africa, emanating from the hearing, were incorporated in the TRC's final Report to the nation (TRC Report Vol 5:316ff, 439ff).

\section{CONCLUSION: "IT SEEMS TO HAVE WORKED”}

What, then, should be said of the religious component of the TRC, of the ongoing debate between the baruti and the lawyers? I would like to leave the last word to Jorge Heine, the Chilean ambassador to South Africa, who with the experience of the Chilean truth Commission behind him was invited to contribute an article to a Sunday newspaper. The TRC had already closed its doors and the final Report was being prepared when Jorge Heine observed (The Sunday Independent, 2 August 1998): 
The powers and resources (of the South African TRC) are much more significant than those of the Chilean commission... Yet, ironically for a body with such strong statutory powers, the South African Commission stands out for the relative absence of lawyers (except the amnesty committee) and an extraordinary religious component. Sitting at the hearings held at the Central Methodist Church in downtown Johannesburg some time ago, watching Archbishop Desmond Tutu say a prayer and Alex Boraine call on some of the witnesses, I could not help but reflect that this would have been unthinkable in many countries where the separation of church and state is taken seriously.

Yet it seems to have worked in South Africa, where there is a great religious diversity but where the strongly Christian subtext of repentance and forgiveness that pervades the Commission's proceedings conveys both the right message as to what reconciliation is all about. It manages to put at ease humble, profoundly decent South Africans who have been offered, often for the first time, the opportunity to state their case...

In the end, it seems that both the baruti and the lawyers had a role to play. Both vice chairperson Boraine and chairperson Tutu intuitively had it right .

\section{Works consulted}

Boraine, A 2000. A country unmasked: Inside South Africa's Truth and Reconciliation Commission, Oxford: OUP.

Bothman, H R (ed) 2000. To remember and to heal. Cape Town: Human and Rosseau. Jeffery, A 1999. The truth about the Truth Commission. Johannesburg: S A Institute for Race Relations.

Krog, A 1998. Country of my skull. Johannesburg: Random House.

Meiring, P 1998. Chronicle of the Truth Commission. Vanderbijlpark: Carpe Diem.

Roodt, D 2000. Om die Waarheidskommissie te vergeet. Daifern: Praag.

Truth and Reconciliation Commission 1998. Truth and Reconciliation Commission of South Africa. Final Report (Volumes 1-5). Cape Town: TRC.

Tutu, D 1999. No future without forgiveness. London: Rider.

Villa-Vicencio, C, \& Verwoerd, W (eds) 2000. Looking back: reaching forward. Cape Town: UCT Press. 